\title{
Impact of Organic and Mineral Fertilization in Pecan Nut on Production, Quality and Antioxidant Capacity
}

\author{
Linda Citlalli Noperi-Mosqueda1, Juan Manuel Soto-Parra1, Esteban Sánchez2*, \\ Francisco Javier Piña-Ramírez ${ }^{1}$, Ramona Pérez-Leal ${ }^{1}$, María Antonia Flores-Córdova ${ }^{1}$, \\ Nora Aideé Salas-Salazar ${ }^{1}$
}

${ }^{1}$ Facultad de Ciencias Agrotecnológicas, Universidad Autónoma de Chihuahua, Chihuahua, México

${ }^{2}$ Centro de Investigación en Alimentación y Desarrollo A. C. Delicias, Chihuahua, México

Email: *esteban@ciad.mx

How to cite this paper: Noperi-Mosqueda, L.C., Soto-Parra, J.M., Sánchez, E., PiñaRamírez, F.J., Pérez-Leal, R., Flores-Córdova, M.A. and Salas-Salazar, N.A. (2019) Impact of Organic and Mineral Fertilization in Pecan Nut on Production, Quality and Antioxidant Capacity. Agricultural Sciences, 10, 227-240.

https://doi.org/10.4236/as.2019.102019

Received: January 30, 2019

Accepted: February 25, 2019

Published: February 28, 2019

Copyright $\odot 2019$ by author(s) and Scientific Research Publishing Inc. This work is licensed under the Creative Commons Attribution International License (CC BY 4.0).

http://creativecommons.org/licenses/by/4.0/

\section{(c) (i) Open Access}

\begin{abstract}
The pecan nut is considered one of the most important dried fruits in the world by its classification as healthy food. The nutritional balance in the harvest is crucial for its impact on the production, quality and content of bioactive compounds. This research was carried out in the city of Aldama, Chihuahua (Mexico), where doses of mineral and organic fertilization were tested in L25 Taguchi structure with 6 factors and 5 levels by factor: nitrogen (N) 0 - $240 \mathrm{~kg} \cdot \mathrm{ha}^{-1}$, phosphate $\left(\mathrm{P}_{2} \mathrm{O}_{5}\right) 0-120 \mathrm{~kg} \cdot \mathrm{ha}^{-1}$, potassium $\left(\mathrm{K}_{2} \mathrm{O}\right) 0-100$ $\mathrm{kg} \cdot \mathrm{ha}^{-1}$, calcium $(\mathrm{CaO}) 0-400 \mathrm{~kg} \cdot \mathrm{ha}^{-1}$, liquid humus $0-3600 \mathrm{~L} \cdot \mathrm{ha}^{-1}$ and solid humus $0-8000 \mathrm{~kg} \cdot \mathrm{ha}^{-1}$. An average yield of $2.2 \mathrm{t} \cdot \mathrm{ha}^{-1}$ was obtained; 145 nuts per kilogram, $60 \%$ of the edible part of the nut. The total phenolic content was $225.9 \mathrm{mg}$ gallic acid g ${ }^{-1}$ and the antioxidant capacity was $180.9 \mathrm{mg}$ Trolox $\mathrm{g}^{-1}$. It is concluded that the factor with the greatest impact on yield, quality and antioxidant capacity in pecan nut was nitrogen. It was also found that the combination of mineral and organic fertilization helps to maintain the production and quality ranges of the nut. In turn, these factors contribute to the increase in the phenolic strength and antioxidant capacity. The optimal fertilization dosis to obtain the maximum levels in production of $3.2 \mathrm{t} \cdot \mathrm{ha}^{-1}$; decrease the number of nuts per kilogram to 135 , increase the percentage of the edible part of the nut to $61.8 \%$, the increase in the total phenolic content to $318.6 \mathrm{mg}$ of gallic acid $\mathrm{g}^{-1}$ and in the antioxidant capacity with $187.2 \mathrm{mg}$ of Trolox $\mathrm{g}^{-1}$, was $184 \mathrm{~kg} \cdot \mathrm{ha}^{-1}$ of $\mathrm{N}, 107.4 \mathrm{~kg} \cdot \mathrm{ha}^{-1}$ of $\mathrm{P}_{2} \mathrm{O}_{5}, 50 \mathrm{~kg} \cdot \mathrm{ha}^{-1}$ of $\mathrm{K}_{2} \mathrm{O}$ y $2777 \mathrm{~L} \cdot \mathrm{ha}^{-1}$ of liquid humus. Finally, the mineral fertilization complemented with organic fertilization is considered a good fertilization strategy for pecan trees and its possible benefits to health and the environment.
\end{abstract}




\section{Keywords}

Carya illinoinensis (Wangen K. Koch), Pecan Nut, Nutrition, Organic

Fertilization, Antioxidants

\section{Introduction}

The pecan nut [Carya illinoinensis (Wangenh.) K. Koch] is considered one of the most important dried fruits in the world. It is native to the southern United States of America and northern Mexico and belongs to the Juglandaceae family. It is a fruit tree that withstands diverse environmental conditions [1]. Commercial plantations are located mainly in New Mexico, Georgia, Louisiana, Texas and northern Mexico. In addition, this fruit has been introduced in other countries [2] [3]. Therefore, the pecan nut is produced in 57 countries in the world. Mexico ranks No. 2 in the world in pecan nut exports, causing an economic income of more than 666 million dollars. Chihuahua is the largest producing state of this fruit [4] [5].

Recent studies have classified the pecan nut as a health-promoting food for human health, since the nuts contain high levels of unsaturated lipids and their regular intake can reduce the risk of cardiovascular diseases, improving the lipid profile and reducing the glucose contents in human beings [6]. In turn, the pecan nut has been classified by its high content of phenolic compounds and antioxidant activity among foodstuffs [7]. The phenolic compounds contained in this fruit are ellagic and gallic acid, catechin, epicatechin, hydrolysable and condensed tannins [8]. It has been shown that phenolic compounds have antioxidant activity, which can help lower incidence of chronic diseases such as Alzheimer's, Parkinson's disease, and some types of cancer [9].

Although several studies have reported a simple relation between the antioxidant capacity and strength of phenolic compounds, this bond can be more complex, since other components of the same plant are involved; such as proteins, carbohydrates and fiber. In addition, other factors such as variety, nut maturity, environmental conditions, cultivation methods and fertilization process and even soil composition have influence on the content of these bioactive compounds [10].

Therefore, the nutritional balance in pecan trees is a significant challenge by the producer due to the direct impact on the quality and harvest yield [11] [12]. Mineral nutrients have essential and specific functions in plant metabolism as activators of enzymatic reactions, osmoregulators and elements of organic structures [13]. Although mineral fertilization in the soil is the most commonly used strategy to improve quality and productivity of crops, this type of long-term fertilization will not be the most effective method in preserving fertility and soil balance [14]. On the other hand, the use of organic fertilizers can improve physical properties, biological activity, soil fertility and crop nutrition, 
although the availability of nutrients is slower [15] [16] [17]. Alternatively, the application of mycorrhizal fungi improves the nutrient uptake [18].

Both the mineral fertilization and organic methods are characterized by advantages and disadvantages, causing a lively debate for a long time. Indeed, a low chemical input is currently preferred [14]. However, there is not enough information on how this fertilization system affects the production and quality of the walnut growing.

\section{Materials and Methods}

\subsection{Experimental Area and Treatments}

The study was conducted during the production cycle of 2016 (March-November 2016), in the municipality of Aldama, Chihuahua, Mexico, with Schley walnut trees from the west of 34 years, $12 \times 12 \mathrm{~m}$ planting distance $(69$ trees per hectare). The climate of the region is dry. The maximum average temperature in 2016 was $27.8^{\circ} \mathrm{C}\left(82^{\circ} \mathrm{F}\right)$ and the average minimum temperature was $11.9^{\circ} \mathrm{C}$ $\left(53.4^{\circ} \mathrm{F}\right)$. Rainfall shows an annual average of $1.2 \mathrm{~mm}$-being July, August and September the highest rainfall time of the year [19]. The predominant type of soil is Xerosol and its physical-chemical properties were the following: $\mathrm{pH}$ 9.15, electrical conductivity (EC) $0.14 \mathrm{dS} \cdot \mathrm{m}^{-1}$, content of organic matter (OM) $2.52 \%$, cation exchange capacity (CEC) $35.87 \mathrm{cmol} \cdot \mathrm{kg}^{-1}$, the macronutrients values were: Nitrogen (N) $18.90 \mathrm{~kg} \cdot \mathrm{ha}^{-1}$, Phosphate (P) $104.37 \mathrm{mg} \cdot \mathrm{kg}^{-1}$, Potassium (K) $966.17 \mathrm{mg} \cdot \mathrm{kg}^{-1}$, Calcium (Ca) $5582.64 \mathrm{mg} \cdot \mathrm{kg}^{-1}$, Magnesium (Mg) $565.49 \mathrm{mg} \cdot \mathrm{kg}^{-1}$, Sulfur (S) $38.44 \mathrm{mg} \cdot \mathrm{kg}^{-1}$. The micronutrients values were: Iron (Fe) $1.76 \mathrm{mg} \cdot \mathrm{kg}^{-1}$, Manganese (Mn) $68.35 \mathrm{mg} \cdot \mathrm{kg}^{-1}$, Copper $(\mathrm{Cu}) 1.36 \mathrm{mg} \cdot \mathrm{kg}^{-1}$, and Boron (B) 0.66 $\mathrm{mg} \cdot \mathrm{kg}^{-1}$.

The fertilizer forms used were: N (UAN 32, 33.67\% N, D 1.32), P (phosphoric acid, $49.02 \% \mathrm{P}_{2} \mathrm{O}_{5}, \mathrm{D} 1.61$ ), $\mathrm{K}$ (potassium thiosulfate $12.63 \% \mathrm{~K}_{2} \mathrm{O}, \mathrm{S} 17.0 \%, \mathrm{D}$ 1.46), $\mathrm{Ca}$ (calcium sulphate Solugyp ${ }^{\mathrm{MR}}, 31.31 \% \mathrm{CaO}, 17.0 \% \mathrm{~S}$ ), liquid humus $\left(8.20 \mathrm{pH}, 4.06 \mathrm{ds} \cdot \mathrm{m}^{-1} \mathrm{CEC}\right.$, Ratio C/N 3.13, composition in percentages: 0.11 $\mathrm{OM}, 0.06 \mathrm{C}, 0.02 \mathrm{~N}, 0.13 \mathrm{P}, 0.13 \mathrm{~K}, 0.01 \mathrm{Ca}, 0.004 \mathrm{Mg}, 0.02$ Sodium (Na); in $\mathrm{mg} \cdot \mathrm{kg}^{-1}$ : 3.70 Iron (Fe), 1.10 Manganese (Mn), $0.11 \mathrm{Zinc}(\mathrm{Zn}), 0.60$ Copper $(\mathrm{Cu})$, 7.33 Boron (B)), Solid humus, OptiHumus ${ }^{\mathrm{MR}}$, (pH 8.12, $10.18 \mathrm{ds} \cdot \mathrm{m}^{-1} \mathrm{EC}$, Ratio C/N 6.57, composition in percentages: $21.70 \mathrm{OM}, 12.59 \mathrm{C}, 1.91 \mathrm{~N}, 0.96 \mathrm{P}, 1.68 \mathrm{~K}$, 3.52 Ca, $1.35 \mathrm{Mg}, 0.27 \mathrm{Na}$; in mg.kg ${ }^{-1}: 11850.29 \mathrm{Fe}, 458.80 \mathrm{Mn}, 173.65 \mathrm{Zn}, 34.04$ $\mathrm{Cu}, 164.74$ B.). N, P, K, Ca were applied to a band of $10 \mathrm{~cm}$ depth.

A Taguchi L25 structure was used for 6 factors and 5 levels for each factor (Table 1) from which 25 treatments were formed by three repetitions. Each repetition consisted of one tree, and mycorrhizal fungi were applied as dynamic factor.

Compost and earthworm humus were treated by aerial fertilization, while mycorrhizal fungi (Sehumic Vam ${ }^{\mathrm{MR}}$, Acaulospora scrobiculata, Gigaspora margarita, Glomus fasciculatum, G. constrictum, G. tortuosum, G. geosporum with 
Table 1. Factors and levels of structure application Taguchi L25.

\begin{tabular}{ccccccc}
\hline \multicolumn{7}{c}{ Factors/Levels } \\
\hline \multirow{2}{*}{ Strength } & $\mathrm{N}$ & $\mathrm{P}_{2} \mathrm{O}_{5}$ & $\mathrm{~K}_{2} \mathrm{O}$ & $\mathrm{CaO}$ & $\begin{array}{c}\text { Liquid } \\
\text { Humus }\end{array}$ & $\begin{array}{c}\text { Solid } \\
\text { Humus }\end{array}$ \\
\hline $\mathbf{0}$ & 0.0 & 0.0 & 0.0 & 0.0 & 0.0 & 0.0 \\
$\mathbf{1}$ & 12 & 6.0 & 5.0 & 20.0 & 180.0 & 400.0 \\
$\mathbf{5}$ & 60 & 30 & 25.0 & 100.0 & 900.0 & 2000.0 \\
$\mathbf{1 0}$ & 120 & 60 & 50.0 & 200.0 & 1800.0 & 4000.0 \\
$\mathbf{2 0}$ & 240 & 120 & 100.0 & 400.0 & 3600.0 & 8000.0 \\
Simple average & 120 & 60 & 50.0 & 200.0 & 1800.0 & 4000.0 \\
\hline
\end{tabular}

20,000 viable spores $\mathrm{kg}^{-1}$ ). They were distributed in four holes of $10-15 \mathrm{~cm}$ depth around the drip area of the tree, consistent with the cardinal points. The doses applied were $0 \mathrm{~kg} \cdot \mathrm{ha}^{-1}$ for repetition $1,15 \mathrm{~kg} \cdot \mathrm{ha} \mathrm{a}^{-1}$ for repetition 2 and 30 $\mathrm{kg} \cdot \mathrm{ha}^{-1}$ for repetition 3 .

\subsection{Yield Components}

Production. During the harvest (beginning of November 2016), trees were vibrated mechanically. The nut was collected and the weight in $\mathrm{kg}$ was estimated for each tree. Production was extrapolated in tons per hectare when multiplying the production per tree by the number of trees per hectare, corrected by a 0.95 factor due to the heterogeneity in the individual production of the trees.

Number of nuts per kilogram. The number of nuts of a $300 \mathrm{~g}$ sample was counted and the value was extrapolated to the weight unit $(\mathrm{kg})$.

Percentage of edible nut. $300 \mathrm{~g}$ were selected to determine the content of edible almonds. The shell was separated from the edible part, weighed separately and the edible percentage was determined. The value allowed to determine the fraction of edible product regarding the total.

The three previous variables were obtained in accordance with the Mexican Standard NMX-FF-084-SCFI-2009 [20].

\subsection{Nut Samples}

Nut samples were selected from the same tree plots in production during the production cycle 2016, with three repetitions. The samples were transported to the Laboratory of the School of Agrotechnological Sciences to be shelled and stored in plastic bags at $-4^{\circ} \mathrm{C}$ until its use.

\subsection{Degreasing of Nuts}

The nut was ground in a food processor and degreased according to the Villareal-Lozoya et al. [10] methodology with slight changes. The samples were homogenized with hexane $(1: 20 \mathrm{w} / \mathrm{v})$. After the homogenizing process, samples were vacuum filtered at $35^{\circ} \mathrm{C}$ through the Buchner funnel and a slow filtration speed 
filter. The homogenate was washed twice more with hexane and the remaining powder was dried at $35^{\circ} \mathrm{C}$. Powder of the degreased nut $(1 \mathrm{~g})$ was placed in $50 \mathrm{ml}$ Falcon tubes and homogenized with $20 \mathrm{ml}$ methanol: water solution $(80: 20, \mathrm{v} / \mathrm{v})$. The Falcon tubes were capped and stored in refrigeration until analysis.

\subsection{Total Phenols}

The total number of total phenols was determined by a method described by Singlenton and Rossi [21] using gallic acid as standard. An amount of $1.5 \mathrm{ml}$ of $2 \% \mathrm{Na}_{2} \mathrm{CO}_{3}$ and $0.5 \mathrm{ml}$ of $50 \%$ Folin-Ciocalteau reagent, $2.75 \mathrm{ml}$ of deionized $\mathrm{H}_{2} \mathrm{O}$ and $0.5 \mathrm{ml}$ of the extract were added to an assay tube. The mixture was then incubated at room temperature and under dark for 60 minutes. The absorbance was measured at $725 \mathrm{~nm}$ in a Thermo Scientific spectrophotometer, G 10S UV Vis. The results were expressed as mg of gallic acid per g dry weight (mg GA $\left.\mathrm{g}^{-1}\right)$. A calibration curve was plotted. The linearity was determined between 0.50 and $4.0 \mathrm{mg} \cdot \mathrm{ml}^{-1}$, using a gallic acid standard of high-purity reagent grade, the calibration was measured in triplicate, the value of the equation was $0.1645 \mathrm{x}+$ 0.009 , with an $r^{2}$ of 0.9994 .

\subsection{Antioxidant Capacity DPPH}

The DPPH (1,1-diphenyl-1,2-picrihidrazil) radical is a stable compound with an intense violet color and whose radiation is absorbed at $517 \mathrm{~nm}$. Therefore, its strength can be determined by spectrophotometric methods Kim et al. [22]. The reaction was made by mixing $2.9 \mathrm{ml}$ of DPPH radical solution with $0.1 \mathrm{ml}$ of plant extract. The mixture was stored at room temperature and protected from light for 30 minutes. Subsequently, the absorbance was measured at $517 \mathrm{~nm}$ using a UV/Vis spectrophotometer. The target used was $80 \%$ methanol, and a calibration curve was plotted. The linearity was determined between 0 and $800 \mu \mathrm{M}$ using a Trolox standard of high purity reagent grade, and the calibration was measured in triplicate, the equation had a value of $0.0007 x+0.6597$ with an $r^{2}$ of 0.9897 . The analyses were measured in triplicate and the results were expressed in $\mathrm{mg}$ of Trolox $\mathrm{g}^{-1}$ in dry weight. Analyzes were measured in triplicate as well and the results were expressed as $\mathrm{mg}$ Trolox $\mathrm{g}^{-1}$ dry weight.

\subsection{Statistical Analysis}

Given the Taguchi L25 factor structure for the generation of treatments, the statistical analysis was conducted using a linear and quadratic response surface by adjusting the surface to determine the factor levels for optimal response. This technique is used when each factor has three or more levels. A response surface is estimated by regression using the method of least squares. For this, the statistical package SAS (SAS Institute Inc., SAS/STAT Software: Usage and Reference, Version 6, First Edition, Cary, NC: SAS Institute Inc., 1989) was used.

The analysis for each response variable included three stages: 1) analysis of regression and contribution of each factor to the adjustment of regression; 2) 
canonical analysis of the response surface to determine the shape of the curve of those factors that had a significant linear response, quadratic and factor interaction; and 3) predicted values as the minimum or maximum response were selected according to the original range of the data. The percentage of increase or decrease of the response variable and each of the factors to reach the required maximum or minimum value is also determined.

The behavior of all the response variables (pooled or not by categories) is summarized in a table where factors and the simple average are specified for each of them. The resulting eigenvalues expressed as percentages of the mean are taken-positive or negative as appropriate. The contribution of the eigenvectors is expressed with rounded signs from 0.25 (a part of the first quartile or greater) such that $0.2501 \leq+\leq 0.3749,0.3750 \leq++\leq 0.6249,0.6250 \leq+++\leq$ $0.8749,++++>0.8750$. The same would apply to negative eigenvectors. In this way, factors will be weighted to determine which ones have more influence on that variable.

\section{Results}

\subsection{Yield Components}

Table 2 shows that the production media was $2.24 \mathrm{t} \cdot \mathrm{ha}^{-1}$. However, the range of data varied from 1.2 to $3.2 \mathrm{t} \cdot \mathrm{ha}^{-1}$. To reach the maximum level of production, it would be necessary to increase the application of $\mathrm{N}$ by $53.7 \%, \mathrm{P}_{2} \mathrm{O}_{5}$ by $13.4 \%$, $\mathrm{CaO}$ by $14.3 \%$ and liquid humus by $54.3 \%$ concerning the media of each of the factors and a decrease in $\mathrm{K}_{2} \mathrm{O}$ by $5.7 \%$ and $10 \%$ solid humus.

Table 3 shows that the factors that had the greatest impact on the production variable were $\mathrm{N}, \mathrm{P}_{2} \mathrm{O}_{5}$ and liquid humus. The media for the number of nuts per kilogram was 145 nuts. Table 2 shows the ranges for this variable of $135-174$. The factors that have the greatest impact were $\mathrm{N}$ and liquid humus (Table 3 ). The percentage of edible nuts had an average of $60 \%$, the ranges in this variable did not show considerable variation. The minimum value was $58 \%$, while the maximum value was $61.8 \%$, to reach the maximum value it would be necessary to increase $\mathrm{N}, \mathrm{K}_{2} \mathrm{O}, \mathrm{CaO}$, liquid humus and solid humus (Table 2). The factors that have the greatest impact on this variable are shown in Table 3, which were $\mathrm{N}, \mathrm{K}_{2} \mathrm{O}$ and $\mathrm{CaO}$.

\subsection{Total Phenols and Antioxidant Capacity}

Table 2 shows the values for the range of total phenols. The minimum value was $207 \mathrm{mg}$ gallic acid (GA) g $\mathrm{g}^{-1}$ and the maximum value of $318 \mathrm{mg} \mathrm{GA} \mathrm{g}^{-1}$ with a mean of $225 \mathrm{mg} \mathrm{GA} \mathrm{g}^{-1}$. The factors that showed the greatest impact were $\mathrm{N}$, $\mathrm{P}_{2} \mathrm{O}_{5}$ and humus liquid, shown in Table 3.

The antioxidant capacity showed a range that varied from 148.89 to $187.24 \mathrm{mg}$

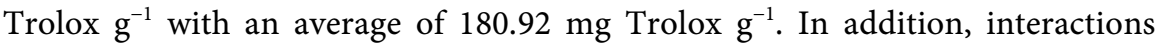
between the different factors were found for this variable; $\mathrm{N}$ showed an interaction with $\mathrm{K}_{2} \mathrm{O}$. On the other hand, $\mathrm{P}_{2} \mathrm{O}_{5}$ with $\mathrm{K}_{2} \mathrm{O}$, liquid humus and solid 
Table 2. Overview of maximum response surface analysis.

\begin{tabular}{|c|c|c|c|c|c|c|c|c|}
\hline \multicolumn{9}{|c|}{ Factors } \\
\hline & & & & $\mathrm{g} \cdot \mathrm{ha}^{-1}$ & & & $\mathrm{~L} \cdot \mathrm{ha}^{-1}$ & $\mathrm{~kg} \cdot \mathrm{ha}^{-1}$ \\
\hline $\begin{array}{l}\text { Response } \\
\text { variable }\end{array}$ & $\begin{array}{c}\text { media/ } \\
\text { optimal/ } \\
\text { Rate-degree \% }\end{array}$ & $\begin{array}{l}\text { Mycorrhizal } \\
\text { fungi }\end{array}$ & $\mathbf{N}$ & $\mathrm{P}_{2} \mathrm{O}_{5}$ & $\mathrm{~K}_{2} \mathrm{O}$ & $\mathrm{CaO}$ & Liquid humus & $\begin{array}{l}\text { Solid } \\
\text { humus }\end{array}$ \\
\hline \multirow{3}{*}{$\begin{array}{l}\text { Production } \\
t \cdot h^{-1}\end{array}$} & & $15.0^{\mathrm{W}}$ & $120.0^{\mathrm{W}}$ & $60.0^{\mathrm{W}}$ & $50.0^{\mathrm{W}}$ & $200.0^{\mathrm{W}}$ & $1800.0^{\mathrm{W}}$ & $4000.0^{\mathrm{W}}$ \\
\hline & $\begin{array}{c}1.2-3.2 \\
2.24^{\mathrm{Z}} \\
(2.5-3.0)\end{array}$ & 13.9 & $\begin{array}{c}184.4^{\star * X} \\
\mathrm{~L}^{\mathrm{Y}}\end{array}$ & 68 & 47.2 & 228.7 & 2777.4 & 3598.9 \\
\hline & $+233.3^{\mathrm{V}}$ & -39.2 & +53.7 & +13.4 & -5.7 & +14.3 & +54.3 & -10.0 \\
\hline \multirow[t]{2}{*}{ Nuts kg ${ }^{-1}$} & $\begin{array}{c}135-174 \\
145 \\
<122\end{array}$ & 14.7 & $152.6^{* *}$ & 52.1 & 60.9 & $\begin{array}{c}230.1 \\
\mathrm{C}\end{array}$ & 2828.9 & 3837.0 \\
\hline & $-29.5^{\mathrm{a}}$ & +1.9 & -27.2 & +13.2 & -21.8 & -15.1 & -57.2 & +4.1 \\
\hline \multirow[t]{2}{*}{$\begin{array}{l}\text { Percentage of } \\
\text { edible nuts }\end{array}$} & $\begin{array}{c}58.0-61.8 \\
60 \\
(\geq 54)\end{array}$ & 14.6 & 120.0 & 60.0 & 50.0 & 200.0 & 1800.0 & 4000 \\
\hline & +6.1 & -0.7 & +43.3 & -2.8 & +29.8 & +16.5 & +82.2 & +14.4 \\
\hline $\begin{array}{l}\text { Total phenols } \\
\text { edible nut mg } \\
\text { GA g }^{-1}\end{array}$ & $\begin{array}{c}207.1-318.6 \\
225.9\end{array}$ & 15.4 & $\begin{array}{c}64.8^{\star *} \\
\mathrm{C}\end{array}$ & 107.4 & 58.0 & $220.3^{* *}$ & $1648.4^{* *}$ & 5391 \\
\hline \multirow{3}{*}{$\begin{array}{l}\text { Antioxidant } \\
\text { capacity edible } \\
\text { nut } \\
\text { mg Trolox g-1 }\end{array}$} & +53.8 & +2.7 & -46.0 & +79.0 & +16.0 & +10.1 & -8.4 & +34.8 \\
\hline & $\begin{array}{c}148.9-187.2 \\
180.9\end{array}$ & 14.8 & $\begin{array}{c}21.6^{\star *} \\
\mathrm{~L}, \mathrm{C} \\
\mathrm{K}_{2} \mathrm{O}\end{array}$ & $\begin{array}{c}50.8^{* *} \\
\mathrm{~K}_{2} \mathrm{O} \\
\text { Liq hum } \\
\text { Sol hum }\end{array}$ & $\begin{array}{c}64.6^{\star *} \\
\text { C } \\
\text { Liq hum }\end{array}$ & $187.6^{* *}$ & $\begin{array}{c}2592.3^{* *} \\
\text { L, C }\end{array}$ & $\begin{array}{c}3424.7^{\star *} \\
\mathrm{~L}\end{array}$ \\
\hline & +25.8 & -1.3 & -82.0 & -15.3 & +29.2 & -6.2 & +44.0 & -14.4 \\
\hline
\end{tabular}

${ }^{\mathrm{X}} \mathrm{F}$-probability for factors: significant ${ }^{*}(0.05 \leq \operatorname{Pr} \leq 0.01)$, highly significant ${ }^{* *}(\operatorname{Pr}<0.01)$, otherwise not significant; ${ }^{\mathrm{Y}}$ response type of linear L regression, quadratic $\mathrm{C}$ and factors interaction; Increase of the response variable regarding the initial value, ${ }^{\mathrm{v}}$ increase or decrease in each factor regarding the simple average; ${ }^{\mathrm{W}}$ media simple of that factor (average between the minimum value and the maximum value explored); ${ }^{\mathrm{Z}}$ General media variable response. ${ }^{a}$ The lowest value for the number of nuts per kilogram is sought; Therefore, the percentages of increase are shown in reverse.

humus, and $\mathrm{K}_{2} \mathrm{O}$ with liquid humus (Table 2). $\mathrm{N}, \mathrm{P}_{2} \mathrm{O}_{5}$ and solid humus were the factors with the greatest impact on antioxidant capacity.

Figure 1(a) shows the interaction of $\mathrm{N}$ with $\mathrm{K}_{2} \mathrm{O}$. It is observed that when combining these two nutrients, the antioxidant capacity increases. In turn, $\mathrm{K}_{2} \mathrm{O}$ when combined with $\mathrm{P}_{2} \mathrm{O}_{5}$, shows a positive synergy to increase the antioxidant capacity (Figure $1(\mathrm{~b})$ ). It is observed that if this interaction is non-existent, $\mathrm{P}_{2} \mathrm{O}_{5}$ would maintain low levels of antioxidant capacity. The liquid humus showed a quadratic response as observed in Figure 1(c), where the maximum point was $181.57 \mathrm{mg}$ trolox $\mathrm{g}^{-1}$ with a liquid humus application of $3621 \mathrm{~L} \cdot \mathrm{ha}^{-1}$, and an interaction with $\mathrm{K}_{2} \mathrm{O}$. The capacity increases up to the maximum levels of $184 \mathrm{mg}$ trolox. $\mathrm{g}^{-1}$ (Figure $1(\mathrm{~d})$ ). 
Table 3. Overview of yield components and antioxidant capacity in pecan tree treated with macronutrients and organic amendments.

\begin{tabular}{|c|c|c|c|c|c|c|c|c|c|}
\hline & \multicolumn{9}{|c|}{ Factors } \\
\hline & \multicolumn{5}{|c|}{$\mathrm{kg} \cdot \mathrm{ha}^{-1}$} & \multirow{2}{*}{$\begin{array}{l}\mathrm{L} \cdot \mathrm{ha}^{-1} \\
\text { Liquid } \\
\text { humus } \\
1800.0\end{array}$} & $\mathrm{~kg} \cdot \mathrm{ha}^{-1}$ & \multirow{2}{*}{\multicolumn{2}{|c|}{$\begin{array}{l}\text { Eigenvectors } \\
\text { Total ratio }+/-\end{array}$}} \\
\hline & $\begin{array}{c}\text { Mycorrhizal } \\
\text { fungi } \\
15.0^{\mathrm{T}} \\
\end{array}$ & $\begin{array}{c}\mathrm{N} \\
120.0\end{array}$ & $\begin{array}{c}\mathrm{P}_{2} \mathrm{O}_{5} \\
60.0\end{array}$ & $\begin{array}{l}\mathrm{K}_{2} \mathrm{O} \\
50.0\end{array}$ & $\begin{array}{c}\mathrm{CaO} \\
200.0\end{array}$ & & $\begin{array}{c}\text { Solid } \\
\text { humus } \\
4000.0\end{array}$ & & \\
\hline \multicolumn{10}{|c|}{ Production $\left(1.26-3.23 \mathrm{t} \cdot \mathrm{ha}^{-1}\right)$} \\
\hline 65.0 & & ++++ & + & & & & & 4 & $4 / 0$ \\
\hline 46.9 & & - & & & ++ & +++ & & 6 & $5 / 1$ \\
\hline-44.5 & & & +++ & ++ & & - & + & 7 & $6 / 1$ \\
\hline Freq. & & 5 & 4 & 2 & 2 & 4 & 1 & 17 & \\
\hline $\mathrm{kg} \cdot \mathrm{ha}^{-1}$ & 13.9 & 184.4 & 68.0 & 47.2 & 228.7 & 2777.4 & 3598.9 & & \\
\hline \multicolumn{10}{|c|}{ Nuts per kilogram (135 - 174) } \\
\hline $21.6^{\mathrm{U}}$ & & $++{ }^{\mathrm{W}}$ & & + & + & +++ & & 7 & $7 / 0$ \\
\hline 13.7 & & --- & & & ++ & + & & 6 & $3 / 3$ \\
\hline-20.1 & & & +++ & + & & & ++ & 6 & $6 / 0$ \\
\hline Freq. & 0 & 5 & 3 & 2 & 3 & 4 & 2 & $19^{\mathrm{Y}}$ & \\
\hline $\mathrm{kg} \cdot \mathrm{ha}^{-1}$ & $15.0^{\mathrm{X}}$ & 120.0 & 60.0 & 50.0 & 200.0 & 1800.0 & 4000.0 & & \\
\hline \multicolumn{10}{|c|}{ Percentage of edible nuts $(58.0 \%-61.8 \%)$} \\
\hline 5.6 & & ++ & & + & & +++ & & 6 & $6 / 0$ \\
\hline 3.5 & & ++ & & ++ & --- & & & 7 & $4 / 3$ \\
\hline-2.8 & & ++ & + & -- & + & - & & 7 & $4 / 3$ \\
\hline-4.1 & & & +++ & ++ & ++ & & & 7 & $7 / 0$ \\
\hline Freq. & 0 & 6 & 4 & 7 & 6 & 4 & 0 & 27 & \\
\hline $\mathrm{kg} \cdot \mathrm{ha}^{-1}$ & 15.0 & 120.0 & 60.0 & 50.0 & 200.0 & 1800.0 & 4000.0 & & \\
\hline \multicolumn{10}{|c|}{ Phenols of edible nuts (207.1 - $318.6 \mathrm{mg} \cdot \mathrm{g}^{-1}$ gallic acid) } \\
\hline 22.9 & & ++++ & & & & - & & 5 & $4 / 1$ \\
\hline 20.7 & & + & +++ & & & & + & 5 & $5 / 0$ \\
\hline-5.5 & & & ++ & -- & + & ++ & -- & 9 & $5 / 4$ \\
\hline-26.0 & & & - & ++ & ++ & ++ & & 7 & $6 / 1$ \\
\hline Freq. & 0 & 5 & 6 & 4 & 3 & 5 & 3 & 26 & \\
\hline $\mathrm{kg} \cdot \mathrm{ha}^{-1}$ & 15.4 & 64.8 & 107.4 & 58.0 & 220.3 & 1648.4 & 5391.0 & & \\
\hline \multicolumn{10}{|c|}{ Antioxidant capacity of edible nuts (148.9 - $187.2 \mathrm{mg} \cdot \mathrm{g}^{-1}$ trolox $)$} \\
\hline 14.6 & & ++++ & & - & & - & & 6 & $6 / 0$ \\
\hline 8.1 & & & --- & ++ & & & ++ & 7 & $4 / 3$ \\
\hline-6.7 & & +++ & ++ & & & & ++ & 7 & $7 / 0$ \\
\hline Freq. & 0 & 7 & 5 & 3 & 0 & 1 & 4 & 20 & \\
\hline $\mathrm{kg} \cdot \mathrm{ha}^{-1}$ & 14.8 & 21.6 & 50.8 & 64.6 & 187.6 & 2592.3 & 3424.7 & & \\
\hline \multicolumn{10}{|c|}{ Overview } \\
\hline Subtotal & 0 & 28 & 22 & 18 & 14 & 18 & 10 & 109 & 109 \\
\hline Selection & $0 / 7$ & $5 / 5$ & $3 / 5$ & $1 / 5$ & $2 / 7$ & $3 / 5$ & $0 / 7$ & & Total ratio +/- \\
\hline Ratio +/- & $0 / 0$ & $24 / 4$ & $18 / 4$ & $13 / 5$ & & $14 / 4$ & & & $89^{\mathrm{z}} / 20$ \\
\hline Maximum & & 184.4 & 107.4 & 50.0 & & 2777.4 & & & \\
\hline
\end{tabular}

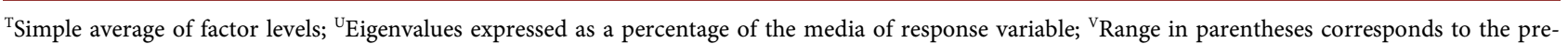
dicted values from the simple average in bold, below the optimal range, underlined above; otherwise optimal values are considered (Soto et al., 2008); ${ }^{\mathrm{W}}$ Each sign corresponds to multiples of 0.25 rounded to the nearest quarter; ${ }^{\mathrm{Y}}$ Total frequency observed for that variable, multiplied by $20 \%$ to select the factors of greater weight; ${ }^{\mathrm{Z}}$ Total frecuency for the set of variables, those factors with a subtotal equal to or greater than $20 \%$ are selected. 


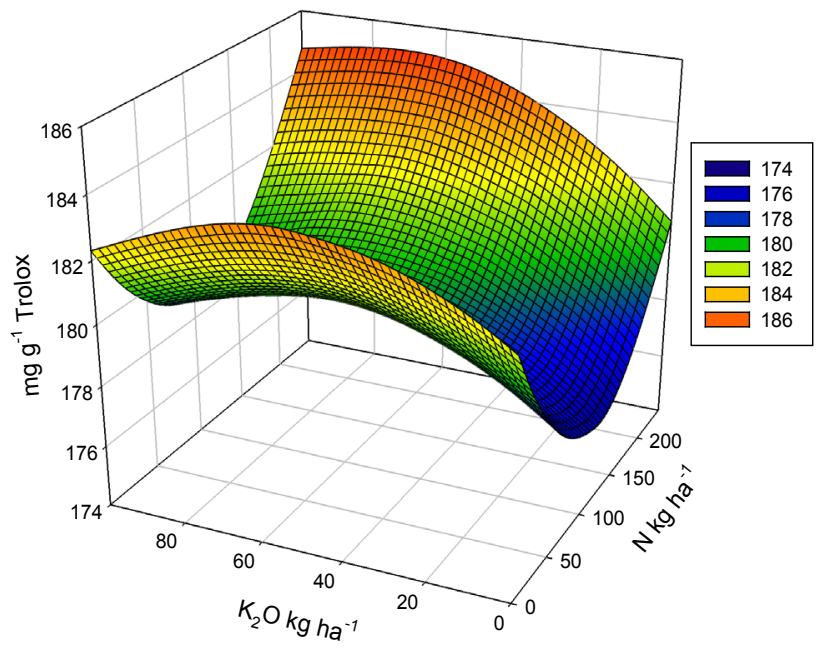

(a)

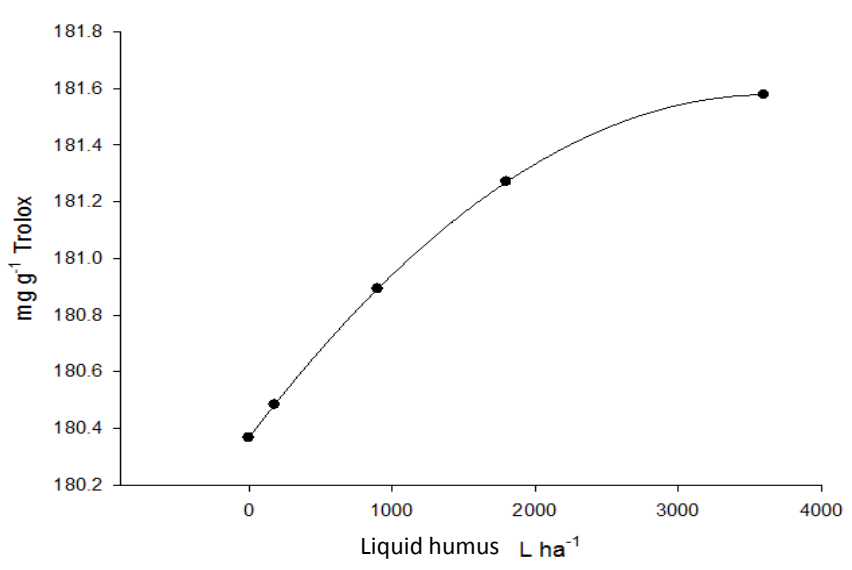

(c)

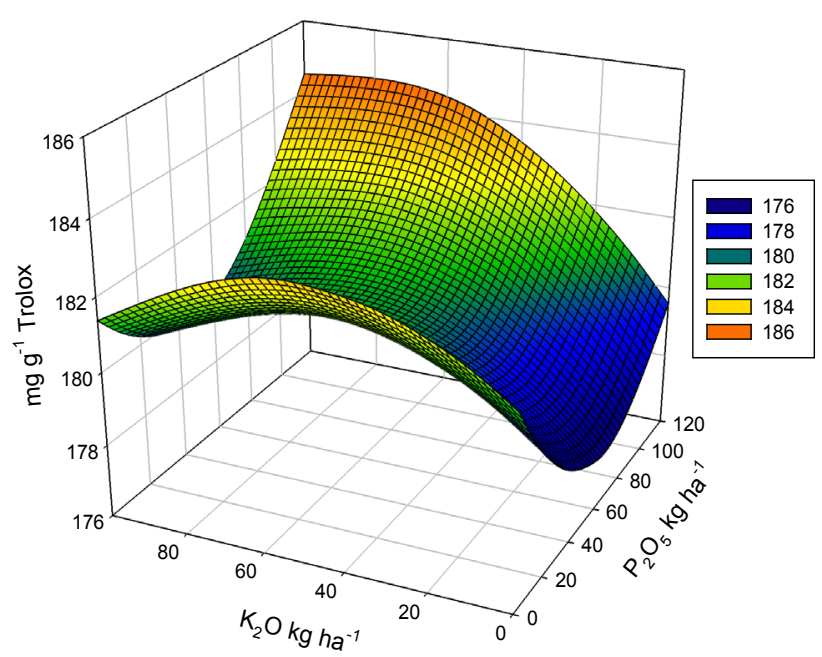

(b)

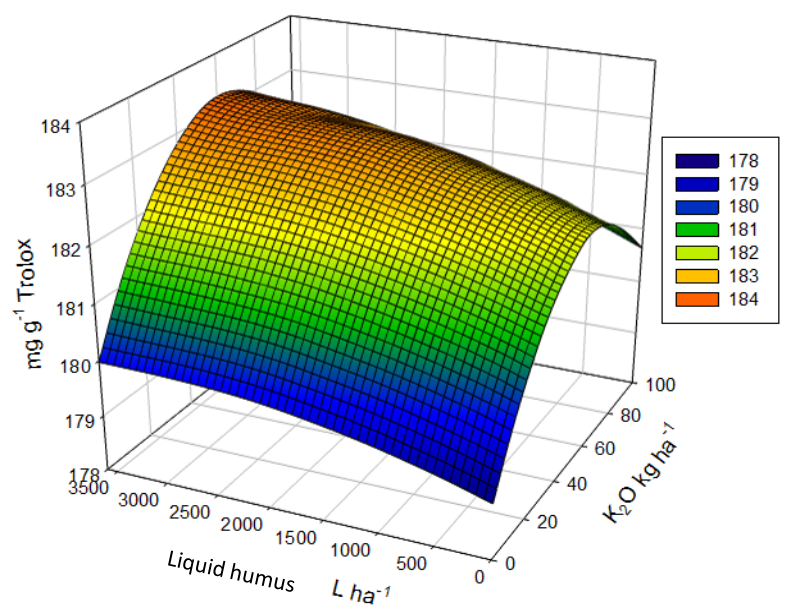

(d)

Figure 1. Response curves showing the interactions for the antioxidant capacity variable. (a) Interaction of $\mathrm{N}$ and $\mathrm{K}_{2} \mathrm{O}$. (b) Interaction between $\mathrm{P}_{2} \mathrm{O}_{5}$ and $\mathrm{K}_{2} \mathrm{O}$. (c) Quadratic response of liquid humus on antioxidant capacity. (d) Interaction between $\mathrm{K}_{2} \mathrm{O}$ and liquid humus.

\section{Discussion}

Previous studies have documented that the mineral and organic fertilization is a good strategy for crop production [14]. For the cultivation of pecan tree, for example, it was reported that it is possible to reduce $\mathrm{N}$ doses when organic amendments are applied to improve soil fertility and nut production [23]. On the other hand, Flores et al. [24] confirmed that the production and quality of the nut crop of the following year can be assured due to the application of $\mathrm{N}$ and organic fertilizers. Additionally, the authors reported that $\mathrm{P}_{2} \mathrm{O}_{5}$ and mycorrhizae have a positive contribution in production, while for the percentage of edible nut, $\mathrm{K}_{2} \mathrm{O}$, earthworm humus and compost were factors with the greatest impact. However, these studies have only been tested on the yield components of pecan nuts and not on the phenolic content and antioxidant capacity of edible nuts. Therefore, in this study, different doses of mineral and organic fertilization were 
tested in pecan trees crops. It was found that the production and quality improved, confirming that the mineral fertilization supplemented by organic fertilization, is a good fertilization strategy for this crop. It was also found that the total phenolic strength and antioxidant capacity increased. Therefore, this study indicates that mineral and organic fertilization contributes positively to the production, quality and antioxidant capacity of the pecan nut.

This is the first study where parameters such as antioxidant capacity and total phenolic content are measured. Results provide compelling evidence to continue investigating the contribution of different fertilization strategies in pecan walnut for these variables and others related to the benefits of nut uptake in human beings. However, the main limitation is that producers are not yet convinced of the use of organic amendments and the impact on the quality of the nut.

Although our hypothesis was supported statistically, the sample does not clearly indicate if this fertilization strategy impacts on other important bioactive compounds for human health. Therefore, the phenolic profile measurement and the fatty acids profile should be included in following works.

This research found that the average production was $2.24 \mathrm{t} \cdot \mathrm{ha}^{-1}$. This value is similar to that reported by Soto et al. [23] where the average production was 2.68 t.ha ${ }^{-1}$ during three years of evaluation. On the other hand, Vázquez et al. [25] reported that the average production in the Comarca Lagunera region in Mexico between 2001-2013 was 1.73 thha ${ }^{-1}$. For its part, SAGARPA [5] reports that the national average production in 2017 was $1.7 \mathrm{t} \cdot \mathrm{ha}^{-1}$, indicating that the average production in our research was higher than the latter reported. On the other hand, Wells and Wood [26] report that $\mathrm{N}$ and $\mathrm{K}_{2} \mathrm{O}$ are related to the production. However, the nitrogen $(\mathrm{N})$ is a nutrient closely related to this variable. This is consistent with our results obtained because $\mathrm{N}$ is an essential factor in production, while $\mathrm{K}_{2} \mathrm{O}$ showed no influence on this variable.

The $\mathrm{N}$ showed an impact on all the evaluated variables. This might be attributed to the fact that $\mathrm{N}$ is one of the most important nutrients for the plants, which is related to the production and quality of fruits [27]. Because the $\mathrm{N}$ is an essential component in the nucleic acids, in amino acids and proteins of plants, it is directly related to the photosynthetic capacity of the plant [28]. As a result of a greater source of $\mathrm{N}$, the plant can increase the production and quality of harvests. At the same time, our results showed that if the maximum values in production are sought to be achieved, the application of $\mathrm{N}$ and liquid humus must be increased. These data are consistent with that reported by Sánchez et al. [27] where the applied doses of $\mathrm{N}$ in pecan nut had an effect directly proportional to the increase in the application of $\mathrm{N}$.

Regarding the total phenolic content and antioxidant capacity, $\mathrm{N}, \mathrm{P}_{2} \mathrm{O}_{5}$ and liquid humus showed an influence on these variables. Nevertheless, there is little information on these variables for mineral and organic fertilization. However, it has been shown that the $\mathrm{N}$ and organic fertilization help to increase the phenolic content and antioxidant capacity as reported by Cucci et al. [14], a study where different doses of mineral and organic fertilization were tested in a legume and 
proved that the organically fertilized treatments maintained and increased the total phenolic content and antioxidant capacity. These results can be attributed to the fact that the use of organic fertilizers improves the release of $\mathrm{N}_{2} \mathrm{P}_{2} \mathrm{O}_{5}$ and $\mathrm{K}_{2} \mathrm{O}$ and other elements, in addition to improving the physical conditions of the soil, which has influence on the crop development and the quality of fruits [17] [18] [24].

It is noteworthy that in this study, the application of mycorrhizal fungi did not show any effect in any of the variables evaluated, which is inconsistent with that reported by Flores et al. [24] who found that the application of mycorrhizal fungi in pecan trees had an impact on the edible percentage and number of nuts per kilogram. On the other hand, Soto et al. [23] reported that the application of mycorrhizal fungi influenced the production and increase of organic matter content in the soil.

On the other hand, the percentage of edible nut, size, color and damage of the fruit are considered for the quality of the nut [27]. According with the Mexican Standard FF-084-SCFI-2009 [20], the quality of the nut can be classified by its size. Our results showed an average of 145 nuts per kilogram. The quality of this nut is classified as large. It is noteworthy that the greater number of nuts per kilogram indicates that nuts are smaller. Therefore, their quality is lower [27]. Thus, we can say that our results are better than those reported by Flores et al. [24] and Soto et al. [23] who found 171 and 163 nuts per kilogram, respectively.

Orona et al. [29] indicates that the percentage of edible nut is an important parameter due to the price of nuts at the time of its commercialization. Our results indicated a mean percentage of edible nut of $60 \%$, which can be qualified as Quality I. In addition, these data are above that reported by Soto et al. [23] that indicate a percentage of edible nut of $58.2 \%$. On the other hand, Flores et al. [24], showed an edible nut percentage of $58.4 \%$. Both results were obtained when mineral and organic fertilization was performed.

The consumer now not only focuses on the good color and taste of products, but also looks for products that provide health benefits. Therefore, parameters such as the total phenolic content in the walnut and the antioxidant capacity were measured. Domínguez-Ávila et al. [6] indicated that nuts such as pecans contain beneficial oils for human consumption and they are also a good polyphenolic source. At the same time, the nut consumption has been linked to a reduction in lipid levels and oxidative stress for human beings. However, these effects have been attributed to those oils contained in the nut, without considering the possible phenolic contribution.

In our results, the mean for total phenolic content was $225 \mathrm{mg} \mathrm{GA} \mathrm{g}^{-1}$. Atanosov et al. [9] reported that the total phenolic content of pecan nuts between two walnut varieties was $20.16 \mathrm{mg} \mathrm{GA} \mathrm{g}^{-1}$ and $15.56 \mathrm{mg} \mathrm{GA} \mathrm{g}^{-1}$ for walnut (Juglans regia). On the other hand, Flores et al. [7] compared a two-year production which reports $82.41 \mathrm{mg} \mathrm{GA} \mathrm{g}^{-1}$ in the low production year and $49.93 \mathrm{mg} \mathrm{GA} \mathrm{g}^{-1}$. It was found that the results were affected by the amount of production that the walnut has; since that overload volume of nuts will alternatively produce lower 
quality nuts. In another study, where the phenolic content was compared in two varieties, the results indicated that the total phenolic content was $23.13 \mathrm{mg} \cdot \mathrm{g}^{-1}$ of the Wichita variety and $19.25 \mathrm{mg} \cdot \mathrm{g}^{-1}$ for the Western variety [30]. The results in our research are superior over those reported by previous authors. This may be because the phenolic strength varies depending on the extraction methods, crop conditions and geographical area of the crop [2] [8].

Alternatively, the antioxidant capacity is correlated with the polyphenolic strength of compounds and some individual polyphenols [8]. The results of antioxidant activity show an average of $180.92 \mathrm{mg}$ Trolox $\mathrm{g}^{-1}$. These results are consistent with those results indicated by Flores et al. [7], who reported values of

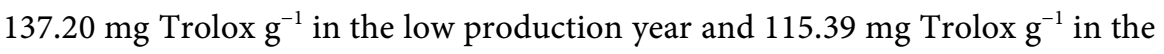
high production year. From this parameter, all the factors show a significant contribution and it is confirmed that the application of organic amendments contributes to improve the quality of nuts [7] [24].

\section{Conclusion}

It is concluded that the $\mathrm{N}$ was a factor with the greatest impact on yield, quality and antioxidant capacity in pecan nuts. It was also found that the combination of mineral and organic fertilization helps to maintain the production and quality ranges of the nut. In turn, these factors contribute to the increase of the phenolic strength and antioxidant capacity. The optimal dose of fertilization to obtain the maximum production, quality, total phenols and antioxidant capacity in pecan tree was: $184 \mathrm{~kg} \cdot \mathrm{ha}^{-1}$ of $\mathrm{N}, 107.4 \mathrm{~kg} \cdot \mathrm{ha}^{-1}$ of $\mathrm{P}_{2} \mathrm{O}_{5}, 50 \mathrm{~kg} \cdot \mathrm{ha}^{-1}$ of $\mathrm{K}_{2} \mathrm{O}$ and 2777 $\mathrm{L} \cdot \mathrm{ha}^{-1}$ of liquid humus. Finally, mineral fertilization supplemented with organic fertilization is considered a good fertilization strategy for pecan trees and its possible benefits to health and the environment.

\section{Conflicts of Interest}

The authors declare no conflicts of interest regarding the publication of this paper.

\section{References}

[1] Peng, H.Z., Jin, Q.Y., Ye, H.L. and Zhu, T.J. (2015) A Novel in Vitro Germination Method Revealed the Influence of Environmental Variance on the Pecan Pollen Viability. Scientia Horticulturae, 181, 43-51. https://doi.org/10.1016/j.scienta.2014.10.057

[2] Pinheiro, P.A., Silvestre, S.H., Mello, M.S., Manique, B.P, Werneck, V.C., Maraschin, M., Salvador, F.S. and Block, M.J. (2014) Effect of the Extraction Process on the Phenolic Compounds Profile and the Antioxidant and Antimicrobial Activity of Extracts of Pecan Nut [Carya illinoinensis (Wangenh) C. Koch] Shell. Industrial Crops and Products, 52, 552-561. https://doi.org/10.1016/j.indcrop.2013.11.031

[3] Zhang, R., Peng, F. and Li, Y. (2015) Pecan Production in China. Scientia Horticulturae, 197, 719-727. https://doi.org/10.1016/j.scienta.2015.10.035

[4] FAO, Food and Agriculture Organization of the United Nations. http://www.fao.org/faostat/es/\#home 
[5] SIAP, Servicio de Información Agroalimentaria y Pesquera. https://www.gob.mx/siap/prensa/atlas-agroalimentario-2017

[6] Domínguez-Avila, J.A., Alvarez-Parrilla, E., López-Díaz, J.A., Maldonado-Mendoza, I.E., Gómez-García, M.C. and de la Rosa, L.A. (2015) The Pecan Nut (Carya illinoinensis) and Its Oil and Polyphenolic Fractions Differentially Modulate Lipid Metabolism and the Antioxidant Enzyme Activities in Rats Fed High-Fat Diets. Food Chemistry, 168, 529-537. https://doi.org/10.1016/j.foodchem.2014.07.092

[7] Flores-Córdova, M.A., Berzoza-Vasquez, P., Sánchez-Chávez, E., Sáenz, S., Guerrero-Morales, S. and Hernández-Carrillo, J. (2016) Composición fisicoquímica y capacidad antioxidante del fruto del pecanero en condiciones de año de elevada producción (“on") y de año de baja producción (“off”). Información Técnica Económica Agraria, 112, 255-270.

[8] De la Rosa, L.A., Vazquez-Flores, A.A., Alvarez-Parrilla, E., Rodrigo-García, J., Medina-Campos, O.N. and Ávila-Nava, A. (2014) Content of Major Classes of Polyphenolic Compounds, Antioxidant, Antiproliferative, and Cell Protective Activity of Pecan Crude Extracts and Their Fractions. Journal of Functional Food, 7, 219-228. https://doi.org/10.1016/j.jff.2014.02.008

[9] Atanosov, A.G., Sabharanjak, S.M., Zengin, G., Mollica, A., Szostak, A., Simirgiotis, M. and Mocan, A. (2017) Pecan Nuts: A Review of Reported Bioactivities and Health Effects. Trends in Food Science \& Technology, 71, 246-257. https://doi.org/10.1016/j.tifs.2017.10.019

[10] Villarreal-Lozoya, J.E., Lombardini, L. and Cisneros-Zevallos, L. (2007) Phytochemical Constituents and Antioxidant Capacity of Different Pecan [Carya illinoinensis (Wangenh.) K. Koch] Cultivars. Food Chemistry, 102, 1241-1249. https://doi.org/10.1016/j.foodchem.2006.07.024

[11] Aguilar, A.C., Soto, P.J., Yáñez, M.R., Sánchez, C.E. and Uvalle, B.J. (2003) Caracterización Nutricional Foliar en Nogal Pecanero (Carya illinoiensis (Wangenh) K. Koch) "Western Schley": Delicias, Chih. Plácido Cuadros S.L., México, 2-21.

[12] Ojeda-Barrios D., Sánchez-Chávez E., Sida-Arreola J., Valdez-Cepeda R., Balandran-Valladares M. (2016) The Impact of Foliar Nickel Fertilization on Urease Activity in Pecan Trees. Journal of Soil Science and Plant Nutrition, 16, 237-247. https://doi.org/10.4067/S0718-95162016005000019

[13] Latsague, M., Sáez, P. and Mora, M. (2014) Efecto de la fertilización con nitrógeno, fósforo y potasio, sobre el Contenido foliar de carbohidratos, proteínas y pigmentos fotosintéticos en plantas de Berberidopsis corallina Hook.f. Gayana Botanica, 71, 37-42. https://doi.org/10.4067/S0717-66432014000100007

[14] Cucci, G., Lacolla, G., Summo, C. and Pasqualone, A. (2019) Effect of Organic and Mineral Fertilization on Faba Bean (Vicia faba L.). Scientia Horticulturae, 243, 338-343. https://doi.org/10.1016/j.scienta.2018.08.051

[15] Márquez, Q.C., Cano-Ríos, P., Moreno, R.A., Figueroa-Viramontes, U., Sánchez, C. E., De la Cruz-Lázaro, E. and Robledo-Torres, V. (2010) Efecto de la fertilización orgánica sobre el rendimiento y contenido nutricional de tomate saladette en invernadero. Información Técnica Económica Agraria, 110, 3-17.

[16] Zaragoza, L.M., Preciado, R.P., Figueroa, V.U., García, H.J., Fortis, H.M., Segura Castruita, M.Á., Lagarda, M.Á. and Madero, T.E. (2011) Aplicación de Composta en la Producción del Nogal Pecanero. Revista Chapingo Serie Horticultura, 17, 33-37.

[17] Bastida, F., Torres I.F., Hernández, T. and García, C. (2017) The Impacts of Organic Amendments: Do They Confer Stability against Drought on the Soil Microbial 
Community? Soil Biology \& Biochemistry, 113, 173-183.

https://doi.org/10.1016/j.soilbio.2017.06.012

[18] Tarango, R.S., Moorillón, V.N. and Borunda, E.O. (2009) Growth, Yield, and Nutrient Status of Pecans Fertilized with Biosolids and Inoculated with Rizosphere Fungi. Bioresource Technology, 100, 1992-1998.

https://doi.org/10.1016/j.biortech.2007.12.078

[19] INIFAP (2018) Instituto Nacional de Investigaciones Forestales, Agrícolas y Pecuarias.

http://clima.inifap.gob.mx/lnmysr/Historicos/Datos?Estado=8\&Estacion=90\&Anio $=2015 \& \mathrm{Mes}=$

[20] Norma Mexicana NMX-FF-084-SCFI-2009.

[21] Singlenton, V.L. and Rossi, J. (1965) Colorimetry of Total Phenolics with Phosphomolybdic-Phosphotunstic Acid Reagents. American Journal of Enology Viticulture, 16, 144-158.

[22] Kim, D.O., Lee, K.W., Lee, H.J. and Lee, C.Y. (2002) Vitamin C Equivalent Antioxidant Capacity (VCEAC) of Penolics Phytochemicals. Journal of Agricultural Food Chemistry, 50, 3713-3717. https://doi.org/10.1021/jf020071c

[23] Soto-Parra, J., Sánchez-Chávez, E., Pérez-Leal, R., Piña-Ramírez, F. and Basurto-Sotelo, M. (2016) Alternativas orgánicas para disminuir la aplicación de nitrógeno en nogal pecanero. Nova Scientia, 8, 140-161. https://doi.org/10.21640/ns.v8i16.413

[24] Flores-Cordova, M.A., Soto-Parra, J.M., Javier-Piña, F.J., Pérez-Leal, R. and Sánchez-Chavez, E. (2018) Contribución de nutrientes, enmiendas orgánicas y micorrizas, sobre los componentes de rendimiento en nogal pecanero (Carya ilinoinensis). Cultivos Tropicales, 39, 35-42.

[25] Vázquez, M.G., Castillo, I.O., Vázquez, C.V., Hernández, M.F. and Arellano, J.D. (2018) Análisis comparativo de huertos de nuez pecanera (Carya illinoensis Koch) en la Comarca Lagunera. Revista Mexicana de Ciencias Agrícolas, 9, 25-35.

[26] Wells, M.L. and Wood, B.W. (2007) Relationships between Leaflet Nitrogen: Potassium Ratio and Yield of Pecan. HortTechnology, 17, 473-479. https://doi.org/10.21273/HORTTECH.17.4.473

[27] Sánchez, E., Soto, J.M., Sosa-Cerecedo, M., Yáñez, R.M., Muñoz, E. and Anchondo, Á. (2009) Eficiencia de uso del nitrógeno en nogal pecanero. Terra Latinoamericana, 27, 311-317.

[28] Sánchez Chávez, E., Ruiz, J.M., Romero, L., Preciado-Rangel, P., Flores-Córdova, M.A. and Márquez-Quiroz, C. (2018) Son los pigmentos fotosintéticos buenos indicadores de la relación del nitrógeno, fósforo y potasio en frijol ejotero? Ecosistemas y Recursos Agropecuarios, 5, 387-398. https://doi.org/10.19136/era.a5n15.1757

[29] Orona, C.I., Sangerman-Jarquín, D.M., Fortis H.M., Vázquez, V.C. and Gallegos Robles, M.Á. (2013) Producción y comercialización de nuez pecanera (Carya illinoensis Koch) en el norte de Coahuila, México. Revista mexicana de ciencias agrícolas, 4, 461-476. https://doi.org/10.29312/remexca.v4i3.1207

[30] Flores-Cordova, M., Sanchez, E., Ojeda-Barrios, D.L., Soto-Parra, J.M. and Preciado-Rangel, P. (2017) Phytochemical Composition and Antioxidant Capacity in Mexican Pecan Nut. Emirates Journal of Food and Agriculture, 29, 346-350. 